\title{
Demineralized Drinking Water in Local Reverse Osmosis Water Treatment Stations and the Potential Effect on Human Health
}

\author{
Hussein Janna ${ }^{*}$, Mukhtar D. Abbas ${ }^{2}$, Mukhlis H. Mojid ${ }^{2}$ \\ ${ }^{1}$ Civil Engineering Department, University of Al-Qadisiyah, Al Diwaniyah, Iraq \\ ${ }^{2}$ Al-Qadisiyah Environmental Authority, Al Diwaniyah, Iraq \\ Email: *Hussein.janna@qu.edu.iq
}

Received 9 February 2016; accepted 22 February 2016; published 25 February 2016

Copyright (C) 2016 by authors and Scientific Research Publishing Inc.

This work is licensed under the Creative Commons Attribution International License (CC BY). http://creativecommons.org/licenses/by/4.0/

(c) (†) Open Access

\begin{abstract}
Water is important for life and its elements are very useful for human body to some extent. Reverse Osmosis (RO) is a very effective method in minimizing the concentrations of some elements in drinking water treatment. Therefore, the goal of this study is to measure the concentrations of some important parameters for human body and the role of Reverse Osmosis (RO) method in the local drinking water treatment stations in minimizing these constituents. This goal was achieved by comparing the effluent of five local drinking water treatment stations that depends on Reverse Osmosis as a primary treatment for the water produced from the Al-Diwaniyah water treatment plant. These parameters are $\mathrm{PH}, \mathrm{EC}, \mathrm{TDS}, \mathrm{Ca}, \mathrm{Mg}$, and TH. Therefore, samples were collected and tested in Al-Qadisiyah Environmental Authority for these local drinking water treatment stations for seven weeks, in order to compare the effluent with the minimum concentrations required for human body according to the health studies and guide lines. The results show that all the drinking waters produced by these stations were below the WHO and Iraq standards. The concentrations of Calcium were in the range from 5.3 to $25 \mathrm{mg} / \mathrm{l}$, while the concentrations of magnesium were in the range from 9.5 to $18.2 \mathrm{mg} / \mathrm{l}$. Therefore, drinking water produced from RO stations should be remineralised to increase the concentrations of necessary constituents in order to minimize the risk of the potential influence of low level concentrations containing calcium carbonate or by adding calcium compounds to the water.
\end{abstract}

\section{Keywords}

Reverse Osmosis, Human Health, Water Treatment, Calcium and Magnesium, Al-Diwaniyah

\footnotetext{
${ }^{*}$ Corresponding author.
}

How to cite this paper: Janna, H., Abbas, M.D. and Mojid, M.H. (2016) Demineralized Drinking Water in Local Reverse Osmosis Water Treatment Stations and the Potential Effect on Human Health. Journal of Geoscience and Environment Protection, 4, 104-110. http://dx.doi.org/10.4236/gep.2016.42012 


\section{Introduction}

Water is important for hydration and, consequently, for life. It is also essential in food preparation and cooking, sanitation and hygiene and for different uses. The safe drinking water must be free from all hazardous materials and contaminant; therefore the primary objective of drinking-water supply is to protect human health, including ensuring access to adequate quantities of safe water [1]. Monitoring drinking water quality is an environmental issue that has big awareness these days. Different chemicals such as pesticides, disinfection by product are the subject of interest while some other constituents are out of focus. There are some elements playing an important role in the public health and representing essential elements for human body activities. Calcium and magnesium are as major representatives of these constituents and for many years these constituents have been extensively considered; however, unexpectedly, a broad range of data available and the knowledge acquired have had a negligible effect on the regulatory field [2].

Teeth and bones contain more than 99\% of total body calcium, where it functions as a key structural element [3]. Several researches have published that calcium absorbed by the body from drinking water or mineral water is more effective than that found in dairy products [4] [5].

Magnesium content is associated to the heart muscle in the water by a positive relation [6]. Enamel in teeth contains calcium, magnesium, and phosphate compounds and therefore the low level of these constituents will make teeth be susceptible to decay induced by acid-producing bacteria [7]. It is a protective factor against cerebrovascular disease (cerebrovascular) [8]. Magnesium deficiency linked to cause several medical issues, such as high blood pressure, irregular heartbeat and diseases, the blood vessels and pre-eclampsia in pregnant women and diabetes type II and osteoporosis [9]-[11].

Hardness is caused by metal cations such as calcium $\left(\mathrm{Ca}^{2+}\right)$, but in fact all divalent cations cause hardness $\left(\mathrm{Ca}^{2+}, \mathrm{Mg}^{2+}, \mathrm{Fe}^{2+}, \mathrm{Sr}^{2+}\right.$, and $\left.\mathrm{Mn}^{2+}\right)$. Total hardness is the direct measurement of hardness $\left(\mathrm{Ca}^{2+}+\mathrm{Mg}^{2+}\right)$. Total hardness in drinking water has an important role, since considerable numbers of studies, for example, in the USA, have indicated a correlation between hardness or TDS and mortality, especially cardiovascular disease [12]. Another study carried out in the UK, confirmed that mortality from cardiovascular disease was closely associated with water hardness [13]. Many epidemiological studies have found an inverse relationship between water hardness and cardiovascular diseases (CVD) [14] [15]. Furthermore, many different types of cancer are like pancreatic cancer [16], esophageal cancer [17], rectal cancer [18], and breast cancer [19].

\section{Experimental Work}

\subsection{Sampling}

Al-Diwaniyah City is one of Iraq provinces and branch of Euphrates pass through the city and divided it into two banks. Five local water treatments stations were selected due to their high rate production and due to the fact that most people in the city of Al-Diwaniya/Iraq are using the water for drinking purposes from these stations. These units are use the treated water from the water treatment plants and treat it with the (RO) system and then filled the plastic bottles in a size of 20 and 10 litres. Samples were collected between February and April 2015. Samples were collected in a polyethylene 1 liter bottles and transferred in a cooling box to the laboratory in Al-Qadisiyah Environmental Authority for analysis. The sampling regime was once a week for seven weeks from the selected five local water treatment units. The parameters were measured are Ca, Mg, TH (Total Hardness), PH, EC (Electrical Conductivity), and TDS (Total Dissolved Solids). Results were tabulated and analyzed using simple descriptive statistics. Independent T-test for two means and analysis of variance for multiple means were used. $\mathrm{P} \leq 0.05$ were considered significant throughout data analysis.

\subsection{Methodology}

The method for determination of Total hardness, calcium, and magnesium depend on the titration with EDTA (Ethylene diamine tetra acetic acid) which is followed the (APHA) [20]. For total hardness, about $50 \mathrm{ml}$ of the water sample was transferred to the conical flask, then 2 - $3 \mathrm{ml}$ of the buffer (pH 10) solution. Followed by adding Eriochrome Black $\mathrm{T}$ to the contents of the flask (add gradually to the flask, swirling after each addition) until a deep wine red color is obtained. Finally titrate the water sample with the EDTA until changing the color from the red to the dark blue.

For the determination of calcium, about $50 \mathrm{ml}$ of the water sample was transferred to the conical flask, then 2 
$\mathrm{ml}$ of sodium hydroxide solution in order to maintained PH between 12 - 13. Followed by adding $0.1-0.2 \mathrm{mg}$ of ammonium purpurate indicator (murexide) to the water sample in the flask in order to turn the sample to the pink color, finally titrate the water sample with the EDTA until changing the color from the pink to the purple and the amount consumed of EDTA can be used in the calculations to find the calcium concentration. For the magnesium, the concentration can be quantified depends on the results of total hardness and calcium calculations.

\section{Results and Discussion}

\subsection{PH, EC, and TDS}

The results of PH, EC, and TDS are shown in the Table 1. For PH values, it can be noticed that from the results of (RO) treatment systems at all local treatment stations show that although the PH value was the lowest mean, however, the results show no significant difference between these stations, since the mean average of $\mathrm{PH}$ value were ranging from (6.4 - 6.9) with an average of 6.7 with standard deviation of 0.2. However, the mean PH value for the station (S2) was the lowest among the selected stations. Figure 1 shows the PH values for these five stations for seven weeks.

For the electrical conductivity (EC), the mean values were about $255.6 \mu \mathrm{S} / \mathrm{cm}$ ranging from (26.0 - 372.8). The results show that there is a significant difference between the station (S2) and the other stations in terms of their EC values.

In terms of Total Dissolved Solids (TDS), the results demonstrate that the concentration of TDS ranging from (16.9 mg/l - $203.5 \mathrm{mg} / \mathrm{l})$. The results show there is a significant difference between the station (S2) and other stations. Figure 2 shows the mean values of these stations for the Total Dissolved Solids and Electrical Conductivity values.

\subsection{Calcium, Magnesium, and Total Hardness}

The results of Ca, Mg and TDS are shown in the Table 2. It can be seen that the results of (RO) treatment systems at all local treatment stations show that the mean of the (DW supply) which represent the raw water for these stations is about (359 mg/l) and the mean total hardness (TH) for the station (S2) was the lowest (high rate

Table 1. Statistical description for PH, EC, and TDS for five stations.

\begin{tabular}{ccccc}
\hline Station Name & N & $\begin{array}{c}\text { PH } \\
\text { Mean }(\text { Std })\end{array}$ & $\begin{array}{c}\text { EC }(\boldsymbol{\mu S} / \mathbf{c m}) \\
\text { Mean }(\text { Std })\end{array}$ \\
\hline S1 & 7 & $6.7(0.3)$ & $303.3(92.0)$ & $\begin{array}{l}\text { TDS }(\mathbf{m g} / \mathbf{l}) \\
\text { Mean }(\text { Std })\end{array}$ \\
S2 & 7 & $6.4(0.3)$ & $26.0(9.4)$ & $172.4(59.9)$ \\
S3 & 7 & $6.9(0.1)$ & $273.9(28.4)$ & $16.9(4.2)$ \\
S4 & 7 & $6.7(0.2)$ & $301.9(69.1)$ & $168.9(32.9)$ \\
S5 & 7 & $6.7(0.2)$ & $372.8(194.4)$ \\
\hline
\end{tabular}

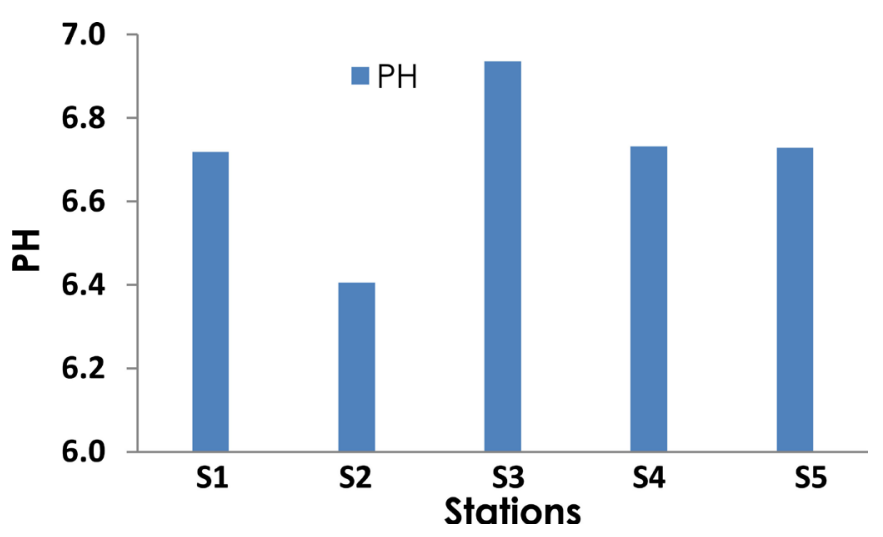

Figure 1. Mean PH values for the five stations. 
of removal); however, there is a significant difference between (S2) and other stations except station (S1) which show no significant difference. Figure 3 shows the mean concentrations of total hardness for the selected stations during the period of study.

In terms of $\mathrm{Ca}$ and $\mathrm{Mg}$, the mean concentrations of the drinking water supply which represent the source for these stations (before passing through the RO systems) were $(90.3 \mathrm{mg} / \mathrm{l})$ and $(31.2 \mathrm{mg} / \mathrm{l})$ for Ca and $\mathrm{Mg}$ respectively. Moreover, the results show that the concentration of $\mathrm{Ca}$ and $\mathrm{Mg}$ at station (S2) were the lowest among the selected stations, where the average concentrations were about $5.3 \mathrm{mg} / \mathrm{l}$ and $9.5 \mathrm{mg} / \mathrm{l}$ for Ca and $\mathrm{Mg}$ respectively. In addition, the results show that there is a significant difference between station (S2) and other stations for both $\mathrm{Ca}$ and $\mathrm{Mg}$ concentration.

In general, it can be noticed that the most mean concentrations of these constituent were lower than Iraqi (IQ STD) and WHO (WHO STD)drinking water standards and also lower than what they were in the previous publications although the influent for these station were (drinking water) were very close to the Iraqi Drinking wa-

Table 2. Statistical description for Ca, Mg, and TH for the selected stations.

\begin{tabular}{cccccc}
\hline Station Name & N & $\begin{array}{c}\text { Ca mg/l } \\
\text { Mean (Std) }\end{array}$ & $\begin{array}{c}\text { Mg mg/l } \\
\text { Mean (Std) }\end{array}$ & $\begin{array}{c}\text { TH mg/l } \\
\text { Mean (Std) }\end{array}$ & $\begin{array}{c}\text { Relative } \\
\text { Ranking }\end{array}$ \\
\hline DW supply & 26 & $90.3(1.2)$ & $31.2(3.3)$ & $359(19)$ & - \\
S1 & 7 & $10.7(4.2)$ & $12.3(8.4)$ & $77.1(42.3)$ & 2 \\
S2 & 7 & $5.3(6.9)$ & $9.5(6.3)$ & $45.7(29.3)$ & 1 \\
S3 & 7 & $11.3(2.4)$ & $13.9(4.7)$ & $85.4(13.8)$ & 3 \\
S4 & 7 & $16.8(3.4)$ & $15.1(8.1)$ & $104.0(29.4)$ & 4 \\
S5 & 7 & $25.0(14.5)$ & $18.2(3.1)$ & $134.3(33.1)$ & 5 \\
\hline
\end{tabular}

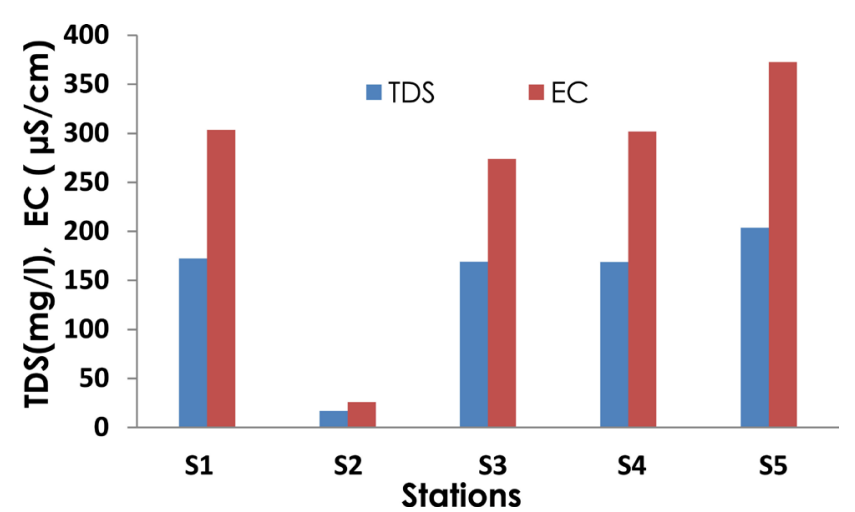

Figure 2. Mean TDS and EC concentrations for the selected stations.

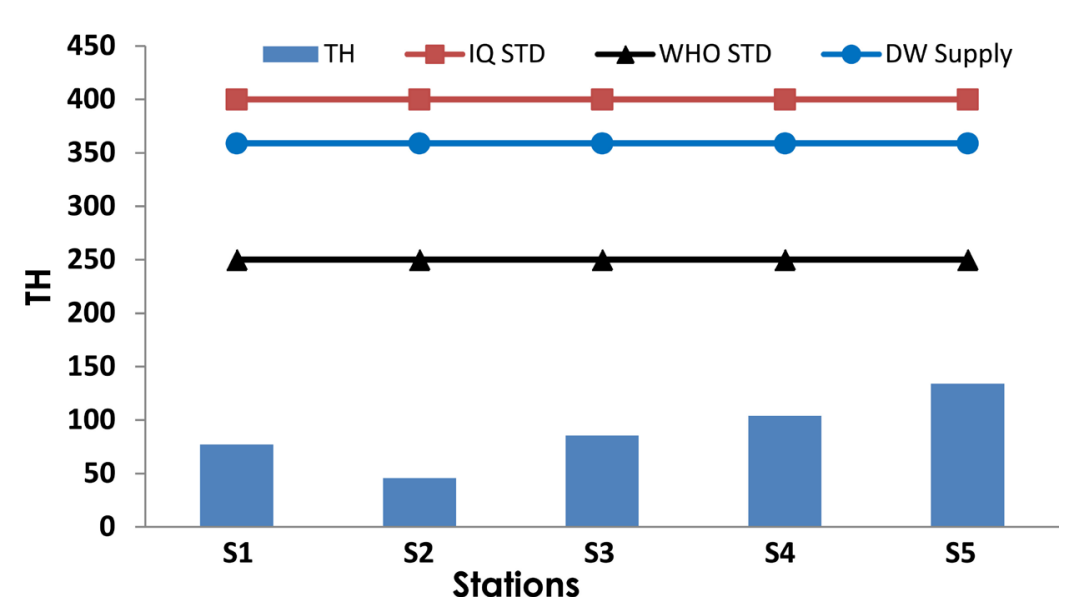

Figure 3. Mean TH values for the five stations. 
ter standards. In addition, due to the reason that all five station have the same water quality (drinking water from the water treatment plant) as influent to these stations, it can be seen that although the station (S2) was the best station in terms of its ability to remove these constituents, however, it is the worst station among the selected station because the high rate removal efficiency and that maybe due to filtration rate and also might be the changing of the filters. Figure 4 and Figure 5 show the mean values of total hardness for the selected stations during the period of study.

Around the world and in many countries, many different researches have published and reported the effect of low intake of calcium and magnesium of human health and activities. They also reported the effect of low calcium and magnesium concentration in the water for the people who drink very soft water.

The study achieved by Yang et al. demonstrated that there is a significant protective effect of calcium intake from drinking water against colon cancer [21], and also against gastric cancer [22]. While Yasui and his colleagues revealed that low calcium and magnesium concentrations in drinking water poses risk of muscle atrophy factor [23].

The results presented by Yang et al. show that there is a significant protective effect of calcium intake from drinking water on the risk of death from acute myocardial infarction (AMI) [24]. Moreover, the results achieved by Chiu et al. demonstrated that there may be a significant protective effect of calcium intake from drinking water against the risk of death due to kidney cancer with a concentration level of about $35 \mathrm{mg} / \mathrm{l}$ and $11.2 \mathrm{mg} / \mathrm{l}$ for Ca and Mg respectively [25]. These values were in accordance with the results carried out in this study and also other studies such as the study achieved by Moyel et al. show that the mean concentration of Ca is ranging from 5.9 - $11.8 \mathrm{mg} / \mathrm{l}$ and from the range of (4.4 - 13.9) mg/l for Mg concentration [26]. Furthermore, Morr, et al. have shown that the results of calcium and magnesium are compatible to what this study found [27].
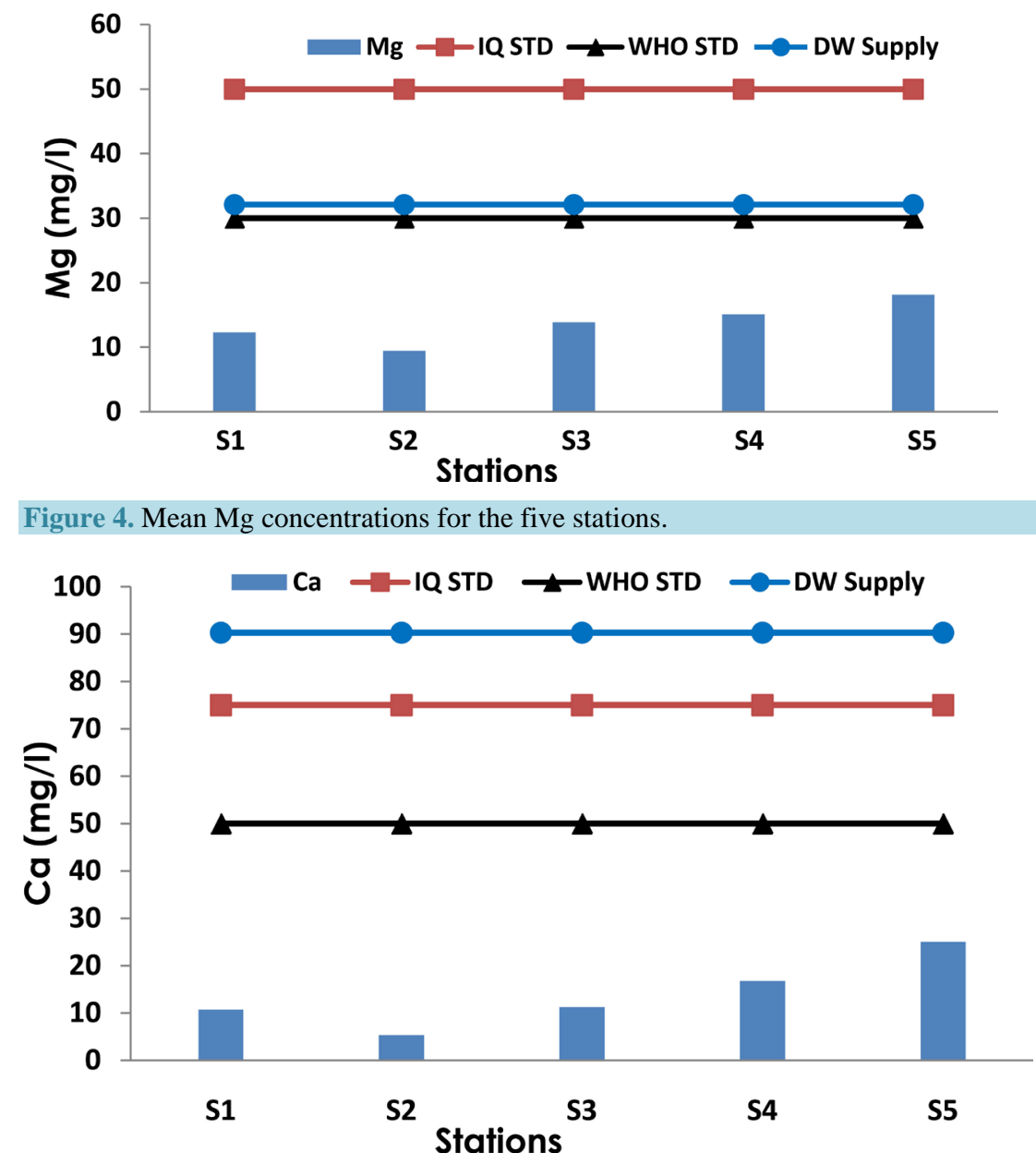

Figure 5. Mean Ca concentrations for the five stations. 
In a simple comparison between the above researches and present study, it is clear that the concentration of Calcium, Magnesium, and Total hardness in the selected RO treatment station in Al-Diwaniyah City is lower than or in the same level of the concentrations in the researches mentioned above, which leads to the fact that there is a high degree of risk to expose to these kinds of diseases (which mean a link between low concentrations and human health). The other issue, when there is a risk from pollution with a specific contaminates in a specific are, then it can be controlled by many different ways, while due the wide speared of these (RO stations) not only in Al-Diwaniyah City, they are all over the Iraqi cities and towns which reflect a potential influence on a wide range of municipalities and towns from the risk of low levels of these constituents.

\section{Conclusion and Recommendations}

The purpose of this study is to compare the concentration of some important constituents (calcium and magnesium) in the potable water with the national and international standards, and also the performance of some local drinking water stations that use the RO system in their treatment. The results show that most of the concentration is below the Iraqi and World Health Organization standards. In addition, the station (S2) was the worst station among the selected stations due to its high degree of removal efficiency to these constituents in the RO system. Therefore, some actions and recommendations are suggested:

- For the use drinking water produced from RO stations, the water should be remineralised by passing through a filter containing calcium carbonate or by adding calcium compounds to the water.

- Raise the awareness and attention of the society about the importance of minerals in water, and how these constituents could prevent from some diseases.

- Environmental authorities should conduct more studies about this issue in order to provide the rational for setting standards.

- Reconsider also if it is necessary to revise and set up a new regulation for TDS and TH.

\section{References}

[1] Gray N.F. (2008) Drinking Water Quality Problem and Solution. Cambridge University Press, Cambridge.

[2] Kozisek, F. (1992) Biogenic Value of Drinking Water. PhD Thesis, SZU, Praha. (In Czech)

[3] World Health Organization (2009) Calcium and Magnesium in Drinking Water: Public Health Significance. World Health Organization, Geneva.

[4] Heaney, R.P. and Dowell, M.S. (1994) Absorbability of the Calcium in High-Calcium Mineral Water. Osteoporosis International, 4, 323-324. http://dx.doi.org/10.1007/BF01622191

[5] Böhmer, H., Müller, H. and Resch, K.L. (2000) Calcium Supplementation with Calcium Rich-Mineral Waters: A Systematic Review and Meta-Analysis of Its Bioavailability. Osteoporosis International, 11, 938-943. http://dx.doi.org/10.1007/s001980070032

[6] Crawford, T. and Crawford, M.D. (1967) Prevalence and Pathological Changes of Ischaemic Heart-Disease in a HardWater and in a Soft-Water Area. Lancet, 2, 229-232. http://dx.doi.org/10.1016/S0140-6736(67)91297-4

[7] Peckham, S. and Awofeso, N. (2014) Water Fluoridation: A Critical Review of the Physiological Effects of Ingested Fluoride as a Public Health Intervention. Scientific World Journal, 2014, Article ID: 293019. http://dx.doi.org/10.1155/2014/293019

[8] Yang, Ch.Y. (1998) Calcium and Magnesium in Drinking Water and Risk of Death from Cerebrovascular Disease. Stroke, 29, 411-414. http://dx.doi.org/10.1161/01.STR.29.2.411

[9] Melles, Z. and Kiss, S.A. (1992) Influence of the Magnesium Content of Drinking Water and of Magnesium Therapy on the Occurrence of Preeclampsia. Magnesium Research, 5, 277-279.

[10] Rude, R.K. (1998) Magnesium Deficiency: A Cause of Heterogenous Disease in Humans. Journal of Bone and Mineral Research, 13, 749-758. http://dx.doi.org/10.1359/jbmr.1998.13.4.749

[11] Saris, N.-E.L., Mervaala, E., Karppanen, H., Khawaja, J.A. and Lewenstam, A. (2000) Magnesium. An Update on Physiological, Clinical and Analytical Aspects. Clinica Chimica Acta, 294, 1-26. http://dx.doi.org/10.1016/S0009-8981(99)00258-2

[12] Lacey, R.F. (1981) Changes in Water Hardness and Cardiovascular Death-Rates. Technical Report 171, Water Research Centre, Medmenham.

[13] Powell, R., Packham, R.F., Lacey, R.F. and Russell, P.F. (1982) Water Quality and Cardiovascular Disease in British Towns. Technical Report 171, Water Research Centre, Medmenham. 
[14] Kousa, A., Moltchanova, E., Viik-Kajander, M., Rytkonen, M., Tuomilehto, J., Tarvainen, T. and Karvonen, M. (2004) Geochemistry of Ground Water and the Incidence of Acute Myocardial Infarction in Finland. Journal of Epidemiology \& Community Health, 58, 136-139. http://dx.doi.org/10.1136/jech.58.2.136

[15] Piispanen, R. (1993) Water Hardness and Cardiovascular Mortality in Finland. Environmental Geochemistry and Health, 15, 201-208. http://dx.doi.org/10.1007/BF00146743

[16] Yang, C.Y., Chiu, H.F., Cheng, M.F., Tsai, S.S., Hung, C.F. and Tseng, Y.T. (1999) Pancreatic Cancer Mortality and Total Hardness Levels in Taiwan's Drinking Water. Journal of Toxicology and Environmental Health, Part A, 56, 361-369. http://dx.doi.org/10.1080/009841099158051

[17] Yang, C.Y., Chiu, H.F., Cheng, M.F., Tsai, S.S., Hung, C.F. and Lin, M.C. (1999) Esophageal Cancer Mortality and Total Hardness Levels in Taiwan's Drinking Water. Environmental Research, 81, 302-308. http://dx.doi.org/10.1006/enrs.1999.3991

[18] Yang, C.Y., Tsai, S.S., Lai, T.C., Hung, C.F. and Chiu, H.F. (1999) Rectal Cancer Mortality and Total Hardness Levels in Taiwan's Drinking Water. Environmental Research, 80, 311-316. http://dx.doi.org/10.1006/enrs.1998.3921

[19] Yang, C.Y., Chiu, H.F., Cheng, M.F., Hsu, T.Y., Cheng, M.F. and Wu. T.N. (2000) Calcium and Magnesium in Drinking Water and the Risk of Death from Breast Cancer. Journal of Toxicology and Environmental Health, Part A, 60, 231-241. http://dx.doi.org/10.1080/00984100050027798

[20] APHA, AWWA and WFF (2005) Standard Methods for the Examination of Water and Wastewater. 21st Edition, Eaton, A.D., Clesceri, L.S., Rice, E.W. and Greenberg, A.E., Eds., American Water Work Association and Water Environment Federation, Denver.

[21] Yang, C.Y., Chiu, H.F., Chiu, J.F., Tsai, S.S. and Cheng, M.F. (1997) Calcium and Magnesium in Drinking Water and Risk of Death from Colon Cancer. Japanese Journal of Cancer Research, 88, 928-933. http://dx.doi.org/10.1111/j.1349-7006.1997.tb00310.X

[22] Yang, C.Y., Cheng, M.F., Tsai, S.S. and Hsieh, Y.L. (1998) Calcium, Magnesium, and Nitrate in Drinking Water and Gastric Cancer Mortality. Japanese Journal of Cancer Research, 89, 124-130. http://dx.doi.org/10.1111/j.1349-7006.1998.tb00539.x

[23] Yasui, M., Ota, K. and Yoshida, M. (1997) Effects of Low Calcium and Magnesium Dietary Intake on the Central Nervous System Tissues of Rats and Calcium-Magnesium Related Disorders in the Amyotrophic Lateral Sclerosis Focus in the Kii Peninsula of Japan. Magnesium Research, 10, 39-50.

[24] Yang, C.Y., Chang, C.C., Tsai, S.S. and Chiu, H.F. (2006) Calcium and Magnesium in Drinking Water and Risk of Death from Acute Myocardial Infarction in Taiwan. Environmental Research, 101, 407-411. http://dx.doi.org/10.1016/j.envres.2005.12.019

[25] Chiu, H.F., Chang, C.C., Chen, C.C. and Yang, C.Y. (2011) Calcium and Magnesium in Drinking Water and Risk of Death from Kidney Cancer. Journal of Toxicology and Environmental Health, Part A, 74, 62-70. http://dx.doi.org/10.1080/15287394.2010.514236

[26] Mohammad, M.S., Ali, A.H., Tarik, N.K., Enas, M.A., Buthaina, Y.M. and Mahasin, A.A. (2013) Comparison of Total Hardness, Calcium and Magnesium Concentrations in Drinking Water (RO), and Municipal Water with WHO and Local Authorities at Basrah Province, Iraq. Marsh Bulletin, 8, 65-75.

[27] Morr, S., Cuartas, E., Alwattar, B. and Lane, J. (2006) How Much Calcium Is in Your Drinking Water? A Survey of Calcium Concentrations in Bottled and Tap Water and Their Significance for Medical Treatment and Drug Administration. HSS Journal, 2, 130-135. http://dx.doi.org/10.1007/s11420-006-9000-9 